\title{
Evaluasi Pengelolaan Sampah Dan Estimasi Umur Pakai Lahan Di TPA Km.13 Kota Muara Teweh Kabupaten Barito Utara
}

\author{
Rahmi Ainun Nadiah ${ }^{*}$, Sari Marlina ${ }^{2 *}$, Rudy Yoga Lesmana ${ }^{*}$ \\ 1,2 Program Studi Teknik Lingkungan Fakultas Teknik dan Informatika, Universitas Muhammadiyah Palangkaraya \\ *surel: rahmiainunnadiah@gmail.com
}

\begin{abstract}
Muara Teweh City is the capital of North Barito Regency which includes 4 (four) villages, namely Malay Village, Lanjas Village, Jambu Village and Jingah Village, with an overall area of 4487.6 ha or $5.4 \%$ of the area of North Barito Regency and the underserved population is only $85 \%$ of the 4 sub-districts in North Barito Regency, therefore it is necessary to Evaluate Waste Management and also Increase the population accompanied by sustainable development. will lead to a higher volume of landfills that must be managed every day. Based on the results of the Evaluation of Waste Management at TPA Km.13 Muara Teweh City consists of guard post buildings / offices, vehicle parking, landfill entrances, heavy equipment garages, vehicle washes, operational roads, drainage channels, lindi water treatment. This will be more difficult because of the limited land for landfills. With a fairly rapid development, ranging from infrastructure to the increase in the population. Such developments will lead to an increase in the volume of waste that must be transported by garbage transport trucks to landfill KM 13.
\end{abstract}

\section{INTISARI}

Kota Muara Teweh merupakan Ibu Kota dari Kabupaten Barito Utara yang meliputi 4 (empat) Kelurahan, yaitu Kelurahan Melayu, Kelurahan Lanjas, Kelurahan Jambu dan Kelurahan Jingah, dengan luas wilayah keseluruhan 4487,6 Ha atau 5,4\% dari luas wilayah Kabupaten Barito Utara dan penduduk yang terlayani hanya $85 \%$ dari 4 kecamatan yang ada di Kabupaten Barito Utara maka dari itu diperlukan untuk Evaluasi Pengelolaan Sampah dan juga Pertambahan penduduk yang disertai pembangunan yang berkelanjutan akan menyebabkan semakin tingginya volume timbunan sampah yang harus dikelola setiap harinya. Berdasarkan hasil Evaluasi Pengelolaan Persampahan di TPA Km.13 Kota Muara Teweh ialah terdiri dari bangunan pos jaga/kantor,parkiran kendaraan, jalan masuk TPA, garasi alat berat, tempat cuci kendaraan, jalan operasional, saluran drainase, pengolahan air lindi. Hal tersebut akan bertambah sulit karena keterbatasan lahan untuk Tempat Pembuangan Akhir (TPA) sampah. Dengan perkembangan yang cukup pesat, mulai dari infrastruktur sampai pertambahan jumlah penduduk. Perkembangan tersebut akan menyebabkan bertambahnya volume sampah yang harus diangkut oleh truk pengangkut sampah ke TPA KM 13.

\author{
Keywords: \\ Evaluation, \\ Waste Management, \\ Landfill, \\ Estimation.
}

Submitted: June 2021

Reviewed: August 2021

Published: August 2021

\section{Kata Kunci:}

Evaluasi, Pengelolaan Sampah, TPA, Landfill,

Estimasi.

Diterima: Juni 2021

Direview: Agustus 2021

Dipublikasi: Agustus 2021 article under the CC-BY-SA License (http://creativecommons.org/licenses/by-sa/4.0/). DOI: https://doi.org/10.33084/mitl.v6i2.2371. 


\section{PENDAHULUAN}

Sampah adalah limbah yang bersifat padat terdiri dari zat organik zat anorganik yang dianggap tidak berguna dan harus dikelola agar tidak membahayakan lingkungan dan melindungi investasi pembangunan [1].

Peningkatan populasi dan perkembangan kota/kawasan pelayanan ataupun hal-hal yang berhubungan dengan peningkatan kondisi sosial ekonomi warga akan membawa dampak terhadap peningkatan jumlah sampah yang dihasilkan.

Permasalahan tersebut membuat pengelolaan sampah sangat diperlukan dengan tujuan terwujudnya kesejahteraan masyarakat [2].

Pertambahan penduduk yang disertai pembangunan yang berkelanjutan akan menyebabkan semakin tingginya volume timbunan sampah yang harus dikelola setiap harinya [3]. Hal tersebut akan bertambah sulit karena keterbatasan lahan untuk Tempat Pembuangan Akhir (TPA) sampah. Kota Muara Teweh merupakan Ibu Kota dari Kabupaten Barito Utara yang meliputi 4 (empat) Kelurahan, yaitu Kelurahan Melayu, Kelurahan Lanjas, Kelurahan Jambu dan Kelurahan Jingah, dengan luas wilayah keseluruhan 4487,6 $\mathrm{Ha}$ atau 5,4\% dari luas wilayah Kabupaten Barito Utara.

Kota Muara Teweh merupakan wilayah yang padat penduduk jika dibandingkan dengan kelurahan/desa lain di Kabupaten Barito Utara yang jarang terdapat pemukiman penduduk. Jarak Kota Muara Teweh dengan Ibu Kota Provinsi Kalimantan Tengah sejauh \pm 318 kilometer[8]. Jumlah penduduk di Kota Muara Teweh pada pada tahun 2019 sebanyak 42.181 jiwa. Dengan perkembangan yang cukup pesat, mulai dari infrastruktur sampai pertambahan jumlah penduduk.

Lahan TPA yang digunakan sebagai lahan landfill harus dikaji lebih dalam guna mengetahui umur pakai lahan TPA, mempersiapkan lahan yang baru apabila lahan yang dulu hampir penuh agar tidak terjadi overload penimbunan sampah dalam beberapa tahun kedepan [4].

\section{METODOLOGI}

Tempat penelitian ini dilaksanakan di TPA Km.13 berlokasi di Jalan Poros Muara Teweh - Puruk Cahu Km.13, Kabupaten Barito Utara, Kalimantan Tengah. Data sekunder yang diperlukan dalam penelitian ini yaitu data jumlah penduduk, data jumlah timbulan sampah eksisting, data pelayanan sampah di Kecamatan Teweh Tengah, Data luas area yang tersedia, peta lokasi TPA. Data primer yang digunakan dalam penelitian ini ialah komposisi sampah, dan timbulan sampah melalui observasi, wawancara, maupun melalui dokumentasi.

\section{HASIL DAN PEMBAHASAN}

\section{Kondisi Eksiting TPA Km.13 Muara Teweh}

TPA Km.13 pertama kali beroperasi pada tahun 2005, sistem proses pengoperasian TPA Km.13 pada tahun 2005 masih memakai sistem open dumping. Sistem open dumping merupakan sistem pembuangan sampah yang masih sederhana dimana sampah yang langsung dibuang ke TPA tanpa ada perlakuan keberlanjutan [5]. Pengelolaan Kebersihan di Kabupaten pada saat ini masih berada di Ibu Kota Kabupaten Barito Utara yaitu kota Muara Teweh yang berada di Kecamatan Teweh Tengah, sedangkan lingkup pelayanan kebersihan meliputi 2 kelurahan yaitu kelurahan Melayu dan kelurahan Lanjas dengan luas 22.117 Ha dan Kecamatan Teweh Baru dengan lingkup pelayanan kebersihan meliputi 2 kelurahan yaitu kelurahan Jambu dan kelurahan Jingah.

\section{Hasil Evaluasi TPA Km.13 Muara Teweh}

Berdasarkan hasil observasi di lapangan kondisi eksisting di TPA Km.13 Muara Teweh masih ada beberapa bagian yang belum memenuhi standar. Berikut ini adalah hasil observasi kondisi eksisting di TPA Km.13 Muara Teweh 
Tabel 1. Observasi TPA Km.13 Muara Teweh

No. Hasil Observasi TPA Keterangan Km.13

\begin{tabular}{llc}
\hline 1. & $\begin{array}{l}\text { Penghitungan volume } \\
\text { sampah }\end{array}$ & - \\
2. & $\begin{array}{l}\text { Kegiatan pemilahan } \\
\text { sampah }\end{array}$ & - \\
3. & Saluran air lindi & $\checkmark$ \\
4. & Pemanfaatan limbah dan & $\checkmark$ \\
5. & $\begin{array}{l}\text { Sarana } \\
\text { Prasarana/infrastruktur }\end{array}$ \\
6. & $\begin{array}{l}\text { Kegiatan } \\
\text { Pengangkutan/operasional }\end{array}$ & $\checkmark$ \\
\hline
\end{tabular}

Sumber: Peneliti 2021

Berdasarkan asal sumbernya sampah secara garis besar dapatdi kelompokkan atas sampah domestik dan sampah non domestik. Sampah domestik, yaitu sampah yang sehari-harinya dihasilkan akibat kegiatan manusia secara langsung [6].

\section{Sumber dan Komposisi Sampah}

Berdasarkan asal sumbernya sampah secara garis besar dapatdi kelompokkan atas sampah domestik dan sampah non domestik. Sampah domestik, yaitu sampah yang sehari-harinya dihasilkan akibat kegiatan manusia secara langsung, misalnya: dari rumah tangga, pasar, sekolah, pusat keramaian, permukiman, dan rumah sakit. Sampah domestik berupa sisa makanan, plastik, kertas, kardus, kain, kayu, kaca, daun, logam, dan kadang-kadang sampah berukuran besar seperti dahan pohon.

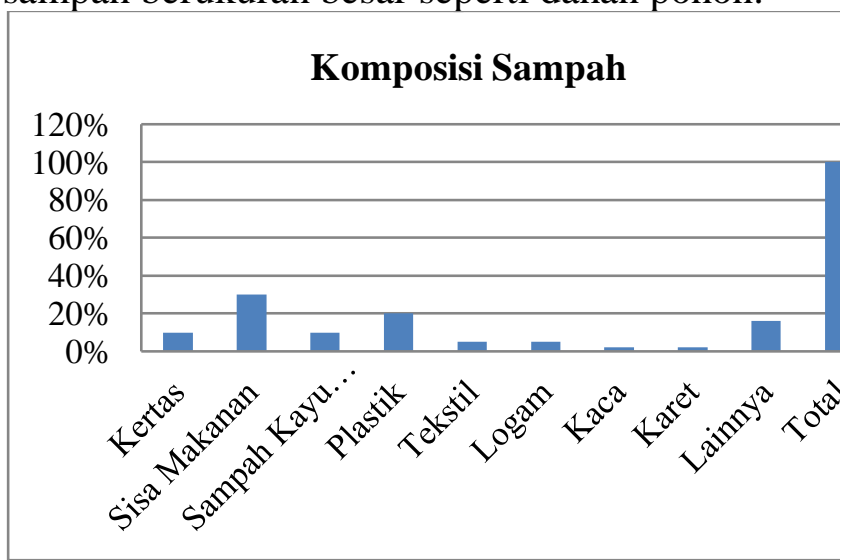

Sumber: SIPSN Kementrian LHK, 2018

TPA Km.13 Muara Teweh memiliki sarana dan prasana TPA yang mendukung kinerja operasional terdiri dari 3 fasilitas, yaitu :

Fasilitas Umum TPA, yaitu sarana dan prasarana yang utama yang harus disediakan pada saat pembangunan TPA. Fasilitas umum TPA Muara Teweh terdiri dari :

\section{a. Jalan Masuk TPA}

Jalan utama untuk masuk ke lokasi TPA Km.13 Muara Teweh dari jalan raya berupa aspal dan mempunyai panjang jalan sekitar 600 meter dengan lebar jalan 3 meter. Jalan utama yang menuju ke TPA berkelokkelok dan relatif curam dan sudah menggunakan model cor jalan. Kondisi jalan operasional di lingkungan TPA juga sudah berupa pengerasan dengan model cor.

\section{b. Pos Jaga dan/atau Kantor Pengelola TPA Km.13}

Pos jaga TPA Km.13 bisa juga disebut sebagai kantor pengelola TPA, dikarenakan pembangunan untuk pos jaga belum dilakukan oleh pihak TPA sehingga untuk pos jaga digabung dengan kantor. Di pos jaga dan/atau kantor merupakan tempat petugas TPA untuk melakukan kegiatan pendataan jumlah sampah yang masuk,

pengelolaan TPA, pemantauan TPA. Untuk kondisi bangunan dari pos jaga dan/atau kantor pengelola mempunyai kondisi bangunan yang cukup baik dengan luas bangunan $60 \mathrm{~m} 2$.

\section{Fasilitas Utama Operasional TPA,} merupakan sarana dan prasana yang menjadi hal utama untuk mendukung jalannya kinerja operasi TPA. Fasilitas utama operasional TPA Km.13 Muara Teweh sebagai berikut:

\section{a. Sel TPA}

Sel TPA Km.13 Muara Teweh sampai sekarang masih mempunyai satu Sel yang masih aktif tetapi, berdasarkan wawancara dengan pihak pengelola TPA Km.13 lahan Sel 2 akan dibuka pada tahun depan yaitu 2022. Sistem di TPA Km.13 Muara Teweh yaitu sistem sanitary landfill yang dimana periode operasi satu sel TPA berlangsung setiap tiga hari sekali atau sesuai dengan kondisi TPA untuk menampung sampah, setelah itu langsung dipadatkan dan ditutup dengan tanah penutup. Mekanisme pengurugan timbulan sampah di lahan TPA KM.13 dilakukan dengan metode teras bangku karena kondisi morfologi Kota Muara Teweh yang sebagian besar berupa dataran tinggi, perbukitan, serta pegunungan, begitu pula dengan kondisi lahan Tempat Pemrosesan Akhir KM.13 yang merupakan dataran yang tidak rata. Pada 
lahan landfill, sampah organik akan diuraikan menjadi gas dan zat cair oleh mikroorganisme di dalam tanah. Untuk ketinggian jarak pengisian yaitu 2 meter.

\section{a. Lapisan Kedap Air/Liner}

Kontruksi dalam suatu TPA Geomembran mempunyai fungsi sebagai lapisan yang kedap air, yang artinya tidak akan menyerap air lindi dari sampah yang ada di TPA.

\section{b. Kolam Pengumpul Lindi}

Dimensi kolam pengumpul berukuran $3138 \mathrm{~m}^{2}$ dan kolam pengumpul lindi yang ada di TPA Km.13 Muara Teweh masih dalam keadaan baik, tetapi sebagian kolamnya ada yang ditumbuhi oleh tumbuhan sehingga kolam tersebut ditutupi oleh tumbuhan liar dan pipa untuk penyaluran lindi juga sebagian ada yang tidak berfungsi dengan baik.

\section{c. Zona Penyangga}

Zona penyangga (buffer zone) yang berfungsi untuk menyangga lahan TPA dan juga menjadi pembatas lahan TPA dengan lingkungan sekitar TPA. Zona penyangga (buffer zone) mempunyai fungsi utama yaitu untuk menghindari polusi udara akibat pembusukan yang terjadi di TPA serta untuk menutup lahan TPA dari lingkungan sekitar TPA yang banyak bangunan lain serta sering dilewati masyarakat. Berikut adalah gambar 4.9 zona penyangga yang ada di TPA Km.13 Muara Teweh. Disekitar zona penyangga TPA Km.13 ditanamin pohon dan saluran drainase yang menuju ke sungai

\section{d. Instalasi Pipa Gas}

Pengolahan gas metan belum dilakukan karena lahan landfill zona 1 masih aktif namun berdasarkan wawancara yang telah dilakukan, gas metan apabila telah dikumpulkan selama beberapa tahun akan digunakan sebagai energi listrik perumahan di area TPA KM.13.
e. Drainase TPA Km.13 Muara Teweh

Berdasarkan hasil observasi lapangan bangunan yang sudah ada di TPA Km.13 Muara Teweh namun masih ada beberapa yang harus diperhatikan yaitu bagian drainase keliling atau pun drainase lokal yang ditengah drainase banyak ditumbuhi rumput liar sehingga menyebabkan terhambatnya aliran air yang mengalir dan drainase kurang berfungsi secara maksimal. Hal ini disebabkan karena kurangnya pemantauan bagunan TPA secara Berkala. Drainase TPA berfungsi untuk mengurangi volume air hujan yang jatuh pada area timbulan sampah selain itu drainase ini juga berfungsi untuk mencegah tergenangnya area timbulan sampah serta menguragi timbulan air lindi. Semakin kecil rembesan air hujan yang masuk ke timbunan sampah, akan semakin kecil pula debit leachate yang dihasilkan. Pada dalam drainase banyak ditumbuhi rumput liar yang mengganggu aliran air di drainase TPA Km.13 Muara Teweh. Untuk ketentuan teknis pembangunan drainase harus sesuai dengan Permen PU No.03 tahun 2013.

\section{Fasilitas Penunjang TPA}

Sarana dan prasana yang mendukung berdiri pengelolaan suatu TPA. Beberapa fasilitas penunjang yang ada di TPA Km.13 Muara Teweh, diantaranya:

\section{a. Bak Komposter Organik}

Pada TPA KM.13 Kota Muara Teweh, pengolahan sampah yang diterapkan yaitu pengolahan sampah organik berupa pengomposan, dan pengolahan air lindi. Pengomposan di TPA KM.13 dilakukan dengan metode bak tertutup.

\section{b. Prasarana Penyedia Air Bersih}

Penyediaan air bersih disuatu lokasi TPA memang sangat diperlukan dalam operasional TPA. Di TPA Km.13 Muara Teweh penyediaan air bersih berjalan dengan lancar dan biasanya digunakan untuk penyediaan air berupa kamar mandi aau dapur di pos jaga TPA, pencucian kendaraan angkut. 
Penyediaan air bersih di TPA juga telah dibuat bak penampungnya.

\section{c. Tempat cuci kendaraan}

Tempat pencucian ini biasanya digunakan untuk mencuci kendaraan yang habis mengangkut sampah dan dibuang ke lokasi TPA. Adanya proses pencucian kendaraan angkut sampah ini untuk mengurangi permasalahan berkaratnya kendaraan dikarenakan terkena bahan-bahan dari sampah yang diangkut yang bersifat korosif.

\section{d. Garasi Alat Berat}

Garasi alat berat di TPA Km.13 Muara Teweh mempunyai ukuran $110 \mathrm{~m} 2$ dan digunakan sebagai penyimpanan kendaraan selama kendaraan tersebut tidak dipakai atau tidak beroperasi. Untuk ukuran garasi penyimpanan alat berat, garasi yang ada di TPA Km.13 Muara Teweh tergolong cukup kecil, sehingga tidak semua alat berat dapat masuk kedalam garasi.

\section{e. Alat berat dan Armada Pengangkutan Sampah}

TPA Km.13 Muara Teweh, mempunyai jumlah operasional untuk alat berat berjumlah unit 2 excavator dan unit 1 buldozer, dan 24 unit armada pengangkutan unit sampah.

\section{Laju Timbulan Sampah di Kota Muara Teweh}

Kota Muara Teweh merupakan kota dengan wilayah cakupan yaitu Kelurahan Melayu dan Kelurahan Lanjas yang berada pada Kecamatan Teweh Tengah serta Kelurahan Jambu dan Kelurahan Jingah yang berada pada Kecamatan Teweh Baru.

Perhitungan Umur Pakai Lahan

\section{Landfill TPA}

Setelah mendapatkan data yang diperlukan dengan cara melakukan perhitungan yaitu seperti proyeksi timbulan sampah, timbulan sampah yang terlayani, dimensi cell, volume daily cover, dan kapasitas zona, maka langkah selanjutnya adalah menganalisis data tersebut. Analisis ini bertujuan untuk menentukan umur pakai lahan landfill
Menurut BPS Kecamatan Teweh Tengah dan Teweh Baru dalam Angka 2020, Jumlah penduduk Kota Muara Teweh pada tahun 2019 adalah sebanyak 42.181 jiwa. Berikut adalah jumlah penduduk berdasarkan kelurahan di Kota Muara Teweh tahun 2010-2020.

Tabel 2. Jumlah Penduduk Kota

Muara Teweh Tahun 2010-2020

\begin{tabular}{ccccc}
\hline \multirow{4}{*}{$\begin{array}{c}\text { Tah } \\
\text { un }\end{array}$} & \multicolumn{4}{c}{ Jumlah Penduduk } \\
\cline { 2 - 5 } & Kec. Teweh Tengah & \multicolumn{2}{c}{ Kec. Teweh Baru } \\
\cline { 2 - 5 } & Melayu & Kel. & Kel. & Kel. \\
2010 & 19.541 & 10.999 & 3.199 & 2.554 \\
2011 & 19.591 & 12.873 & 3.261 & 2.954 \\
2012 & 19.639 & 11.137 & 3.202 & 2.584 \\
2013 & 19.712 & 11.199 & 3.232 & 2.619 \\
2014 & 20.740 & 13.449 & 3.356 & 3.034 \\
2015 & 20.993 & 13.574 & 3.356 & 3.034 \\
2016 & 21.105 & 13.686 & 3.415 & 3.088 \\
2017 & 21.269 & 13.792 & 3.441 & 3.112 \\
2018 & 21.427 & 13.894 & 3.467 & 3.135 \\
2019 & 21.559 & 13.980 & 3.488 & 3.154 \\
2020 & 21.665 & 14.102 & 3.500 & 3.180 \\
\hline
\end{tabular}

(Sumber: Data BPS 2010-2020)

Berdasarkan Tabel 2. jumlah penduduk di Kota Muara Teweh pada tahun 2012 mengalami penurunan dan kembali mengalami kenaikan pada tahun 2013 sampai 2020. Pertambahan jumlah penduduk berkaitan erat dengan kenaikan jumlah timbulan sampah. Semakin besar jumlah penduduk maka semakin besar volume timbulan sampah yang dihasilkan, dengan mengetahui proyeksi jumlah penduduk maka dapat diproyeksikan juga jumlah timbulan sampah yang dihasilkan

TPA, mempersiapkan lahan yang baru apabila lahan yang dulu hampir penuh agar tidak terjadi overload penimbunan sampah kedepannya.

Perhitungan:

1. Sisa Daya Tampung \& Daily Cover $=60.445,65 \mathrm{~m} 3$

2. Timbunan Per Hari 2021 \& Daily Cover

$=79,26 \mathrm{~m} 3 /$ hari 
3. Sisa Hari

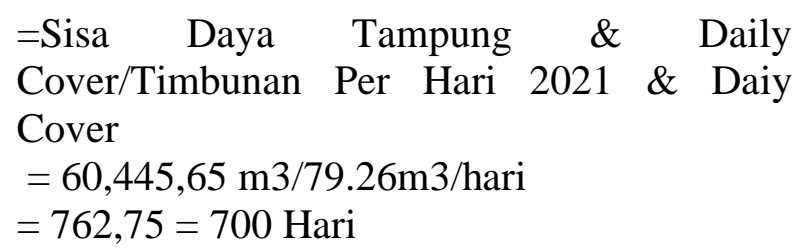

1. Sisa Daya Tampung \& Daily Cover

$=324.520,01 \mathrm{~m}^{3}$

2. Timbunan Per Hari 2050 \& Daily Cover

$=116.34 \mathrm{~m}^{3} /$ hari

3. Sisa Hari

$=$ Sisa Daya Tampung \& Daily

Cover/Timbunan Per Hari 2050 \& Daiy

Cover

$=324.520,01 \mathrm{~m}^{3} / 116.34 \mathrm{~m}^{3} /$ hari

$=2,838=2$ Hari

\section{KESIMPULAN}

Berdasarkan hasil evaluasi TPA Km.13 Muara Teweh terdiri dari bangunan pos jaga/kantor,parkiran kendaraan, jalan masuk TPA, garasi alat berat, tempat cuci kendaraan, jalan operasional, saluran drainase, pengolahan air lindi dan Estimasi umur pakai lahan TPA KM.13 Kota Muara Teweh dengan persentase wilayah yang terlayani sebanyak $85 \%$ yaitu pada Zona 1 dengan kapasitas zona $89.013,25 \mathrm{~m}^{3}$ dapat digunakan selama 700 hari , sedangkan Zona 2 dengan kapasitas zona sebanyak $366.465,81 \mathrm{~m}^{3}$ selama 30 tahun tersisa 2 hari.

\section{SARAN}

Untuk instansi yang menangani bidang persampahan diharapkan kedepannya pengolahan sampah seperti pengomposan dan pengadaan bank sampah dapat kembali dioperasikan guna mengurangi volume timbulan sampah di TPA dan agar lahan landfill dapat bertahan lebih lama apabila adanya upaya daur ulang, pengomposan, serta reduksi sampah dan untuk kedepannya pemerintah dan organisasi swasta perlu mengadakan sosialisasi mengenai pengelolaan sampah yang baik untuk menaikkan kesadaran masyarakat agar dapat memilah dan mengolah sampah yang mereka hasilkan untuk dapat mengurangi jumlah sampah yang akan diangkut ke TPA agar panjang umur pakai lahan di TPA.

\section{REFERENSI}

[1] Abd Hamid, K. B., Ishak, M. Y., \& Abu Samah, M. A. (2015). Analysis of Municipal Solid WasteGeneration and Composition at Administrative Building Café in Universiti Putra Malaysia: A Case Study. Polish Journal of Environmental Studies, 24(5).

[2] Aziz Q.S., Aziz A.H., Yussof S.M., Bashir J.K.M. dan Umar M. 2010. Leachate Characterization In SemiAerobic and Anaerobic Sanitary Landfills: A comparative study. Journal of Environmental Management Vol. 91

[3] Damanhuri, E., Ismaria, R. dan Padmi, T. 2006. Pedoman Pengoperasian dan Pemeliharaan Tempat Pembuangan Akhir (TPA) Sistem Controlled Landfill dan Sanitary Landfill. Jurusan Teknik Lingkungan Fakultas Teknik Sipil dan Perencanaan, Institut Teknologi Bandung.

[4] Chena Y.C., Chen K.S., Wu C.H. 2003. Numerical Simulation of Gas Flow Around a Passive Vent In a Sanitary Landfill. Journal of Hazardous Materials B100, 39-52.

[5] Hogland, W., Marques, M. dan Nimmermark, S., 1999. Landfill mining and waste characterization: a strategy for remediation of contaminated areas. Journal of Material Cycles Waste Management Vol. 6, pp. 119-124.

[6] Nasution, S.R., \& A.R.I. Tjahjani. 2019. Analisis Laju Timbulan Sampah di Pulau Pramuka DKI Jakarta. Jurnal Ilmiah Teknik Industri. 7(1): 16 - 26. 